\title{
Social Cohesion of Local Wisdom for Plural Communities
}

\author{
Alis Asikin \\ Universitas Islam Negeri Waisongo Semarang, Indonesia \\ Email: alis.askin@walisongo.ac.id
}

\begin{abstract}
Local culture and traditions represent local wisdom. Values applied in society. These values are believed to be accurate and become references in their daily behavior. The values of local knowledge are considered influential factors in determining the status and dignity of humans in their communities. Because these values contain intelligence, creativity, and local wisdom from their ancestors, figures, and society. The value of local wisdom that remains in our community is the nyadran ritual tradition. Nyadran is considered a socio-religious and socio-cultural reflection even as a social, cultural, and religious transformation. Nyadran is an expression of social piety where cooperation, solidarity, and togetherness are the main patterns of this tradition. The tradition in Jetis hamlet is in many ways able to develop primordial bonds in a cluster with the same beliefs and views despite different religions and beliefs. This research includes qualitative-exploratory research that requires qualitative data. As a case study, this research uses an ethnographic study approach, which is a tool for analyzing local wisdom whose data sources come from informants.

Keywords: Social Cohesion, Local Wisdom, Social Traditions, Nyadran, Plural Society.
\end{abstract}

\begin{abstract}
Abstrak
Budaya dan tradisi lokal sebagai representasi kearifan lokal, nilai-nilai yang diterapkan dalam masyarakat, nilai-nilai ini diyakini benar dan menjadi acuan dalam perilaku mereka sehari-hari. Nilai-nilai kearifan lokal ini dianggap sebagai faktor yang berpengaruh dalam menentukan status dan martabat manusia dalam komunitasnya. Sebab di dalam nilainilai tersebut mengandung kecerdasan, kreativitas, dan kearifan lokal dari nenek moyang, tokoh, dan masyarakatnya. nilai kearifan lokal yang masih tersisa di masyarakat kita adalah tradisi ritual nyadran. Nyadran
\end{abstract}


dianggap sebagai refleksi sosial-keagamaan dan sosial-budaya bahkan sebagai transformasi sosial, budaya, dan keagamaan. Nyadran merupakan ekspresi kesalehan sosial dimana gotong royong, solidaritas, dan kebersamaan adalah pola utama dari tradisi ini, tradisi di dusun Jetis ini dalam berbagai hal mampu mengembangkan ikatan primordial dalam satu cluster yang memiliki keyakinan dan pandangan yang sama meskipun agama dan kepercayaan yang berbeda. Penelitian ini termasuk penelitian kualitatif-eksploratif yang membutuhkan data kualitatif. Sebagai studi kasus, penelitian ini menggunakan pendekatan studi etnografi. Yang merupakan alat untuk menganalisis kearifan lokal yang sumber datanya berasal dari informan.

Kata kunci: Kohesi Sosial, Kearifan Lokal, Tradisi Sosial, Nyadran, Masyarakat Plural.

\section{Introduction}

Every religion appears in a pluralistic environment and will undergo a metamorphosis process in response to this plurality. The creative tension generated in the context of plurality often becomes a catalyst for new insights in the development of religion itself. In fact, the diversity (plurality) of society is a historical reality that cannot be denied by anyone, especially religious plurality. Pluralism cannot be understood simply by saying that society is in plurality or diversity which only describes the impression of fragmentation, not pluralism. Pluralism also cannot be understood only as "negative good" (negative good), only seen from its use to eliminate fanaticism (to keep fanaticism at bay). However, pluralism must be understood as "a true connection between diversity within ties of civility" (Madjid, 2014). Pluralism is the true confluence of diversity in bonds of civility (Hartono, 2012). In a plural society what is needed is not an "ideal language" that is reductive-positivistic, but what is needed is a more modest social sensitivity to fully appreciate diversity (Crevello, 2004).

These ties of civility to a plural society are something that is inevitable, because on the one hand religion teaches each adherent to carry out ritualistic activities, while on the other hand, people's beliefs at the cultural level are also full of ritual activities seen in traditional ceremonies. The series in this traditional ceremony is partly the result of acculturation between religion and local culture. This is what so called that religion as a cultural system (Geertz, 1973).

Local culture and traditions can functionally be social cohesion that is able to maintain the environmental situation in order to remain 
harmonious, both with fellow humans and the surrounding natural environment. These local traditions have important meanings and values, including as a reference for behavior for people in living life, including dealing with differences in interacting with other people of different cultures and religions (Sukramran, 1984).

These local traditions are actually the expression of local knowledge (local knowledge) or local wisdom (local wisdom) of a community in responding to the situation of the environment (Shalahuddin, 2010). Substantially, local wisdom is the values that apply in a society. These values are believed to be true and become a reference in the daily behavior of the local community (Kongprasertamorn, 2007). These local wisdom values are seen as an entity that really determines human dignity in the community because it contains elements of intelligence, creativity and local knowledge from elites (figures) and the community (Escobar, 1994).

The values of local wisdom in the form of traditions and social norms in society can functionally strengthen the cultural system as a reference in community life, which is then believed and recognized as an important element so as to strengthen social cohesion among community members (Haba, 2007). Thus local wisdom can become an element of social cohesion in interfaith, even cross-cultural life, so that it can give color to togetherness dynamically and peacefully, especially for plural and multicultural communities.

One of the values of local wisdom that still survives in the community is the ritual tradition of Nyadran (Koentjaraningrat, 1990). Besides Nyadran, local culture is also known such as alms of the earth (tradition of praying together for the safety of nature. It is usually done in the month of Apit-Javanese term or Dzul Qadah in Islamic month), etc.

Nyadran or sadranan is an expression of socio-religious reflection. This rite is understood as a form of preservation of the traditional and cultural heritage of the ancestors. Thus, it is not surprising that the implementation of nyadran is still thick with Hindhu-Buddhist ritual traditions and animism acculturated with Islamic values (Dhavamony, 1995).

In socio-cultural terms, the implementation of the nyadran rite is not only limited to ceremonial cleaning of ancestral graves, salvation (kenduri), making apem cakes( kue apem), compote (kolak), sticky rice (ketan), and various snacks from the market (jajan pasar) which are used as elements of "offerings" as well as being a prerequisite for 
the ritual prayer procession. Apem cake is a symbol of the intention to forgive each other. Kolak means a condition of togetherness that is always strived to be realized. Sticky rice means a strong sense of brotherhood attached to each person. Meanwhile, market snacks are a symbol of community assimilation in differences in religion, belief and character . However, the Nyadran ritual in a socio-cultural context has also become a medium of friendship between families and communities, as well as a social, cultural and religious transformation. Nyadran is an expression and expression of social piety in a society where a sense of mutual cooperation, solidarity, and togetherness is the main pattern of this tradition (Geertz, 1983). Nyadran can be used as a vehicle and medium for social glue, a means of building harmony between fellow humans (Marjanto, 2012). In the Nyadran tradition, togetherness is reflected in the community. Thus, the nyadran tradition can become social cohesion for plural communities who have different social, cultural and religious backgrounds.

On the basis of this background problem, the authors are interested in conducting further studies on the nyadran tradition in Jetis Village, both related to its implementation procession, the values of local wisdom contained therein, as well as social cohesion in the nyadran tradition which can strengthen social relations. for the local plural community.

The place of this research was carried out in Jetis Village, Karangrayung District, Grobogan Regency which is in the Central Java Province. This location was determined because the village of Jetis has the potential for local culture that is different from other villages in Grobogan district. The research method used in this research is descriptive qualitative method and case studies with an ethnographic study approach. This method is used because it relates to local wisdom studies using data from informants. The qualitative research method is carried out in a natural setting (natural setting) and the data collected is qualitative. The qualitative method is more based on a phenomenological philosophy that prioritizes appreciation. Qualitative methods attempt to understand and interpret the meaning of an event of human behavior interaction in a particular situation. According to Robert Yin K, case studies are widely used in social science research, both in traditional disciplines (psychology, sociology, political science and anthropology).

Case studies are also often used as research related to regional planning studies, public administration, general policy and 
management science (Hogg, 2004). This study will be very suitable with a research regarding how or why. So that case studies are also used as a research method to complement the qualitative descriptive method. In this study, researchers used an ethnographic approach. Ethnographic studies describe and interpret culture, social groups or systems. Although the cultural meaning is very broad, ethnographic studies usually focus on patterns of activity, language, beliefs, rituals and ways of life. An ethnographer focuses his attention on the details of local life and relates it to broader social processes.

In this study, the sampling technique was carried out by purposive sampling, namely by determining randomly or randomly. Because this research is a qualitative descriptive metod, when the data or information obtained is representative and is considered valid from an informant, the data already represents all the samples to be studied. In this study, researchers extracted information from several community leaders, interfaith leaders and communities who followed interfaith Nyadran. The data analysis method used in this research is qualitative data analysis method. This process is carried out by the following processes: (1) recording what produces field notes, with it coded so that the data source can still be traced; (2) collect, classify; (3) thinking, making explanations, looking for and finding patterns and relationships, and making general findings. This conclusion is drawn by matching the data obtained in the study.

\section{Results and Discussion}

\section{Implementation of interfaith Nyadran Tradition}

Nyadran in Jetis Village first occurred in 1575. At that time Kanjeng Adipati Mertoloyo had finished building Jetis in the month of Sha'ban in 1757. To express gratitude to God for the completion of Jetis construction, Adipati Mertolo conducted a submarine ceremony. In addition, the implementation of Nyadran is carried out in the month of Sha'ban as well to welcome the arrival of the holy month of Ramadan.

Since 1757 until now the Nyadran tradition in Jetis Village is always held every Sha'ban Month. The creativity of Jetis Village residents who intensively explore the art of making the nyadran tradition more lively from year to year with various art performances without reducing the meaning of nyadran itself. 
The peak of the Nyadran program in Jetis Village is held on the last day of the month of Sha'ban. However, on previous days the residents had prepared various kinds of events to welcome the event. On Sundays, five days before the implementation of the Nyadran, residents have organized a carnival to surround their village and surrounding areas. The carnival is also held as a notification and reminding residents in the Jetis village area that on Friday the Nyadran tradition will be held and at the same time as a sign that the month of Sha'ban will end and the next day is the month of Ramadan. So Muslims are obliged to fast.

Three days before the implementation of the nyadran, residents began to busy arranging the place to carry out the nyadran. The village streets are decorated with colorful flags to enliven the atmosphere. The Sasana Krida Budaya art gallery which will be the center for the activities of the nyadran tradition is decorated in such a way. All the mothers and women prepare tenong which is decorated with colorful paper on the outside.

The tenong will later be filled with rames rice, market snacks, and fruits which will be served at the Nyadran event. Various traditional arts are also prepared in such a way to enliven the Nyadran event (Purwanto, 2017).

Before the main Nyadran event was held, the Jetis people opened their houses for an outdoor gathering or gathering like an Eid atmosphere, with the aim of strengthening relationships individually and socially. On Friday nights before the main Nyadran program is held, the tayub dance or better known as the tayuban is held first. In the morning at the peak of the Nyadran event, all residents from various walks of life consisting of various religions are involved in this nyadran ritual. Even the residents of Jetis Village who live outside the city are busy doing the Nyadran homecoming tradition, because they don't want to miss the annual momentum that has been running for hundreds of years.

The Nyadran program begins with a pilgrimage to the ancestral graves, namely the graves of Kanjeng Adipati Mertoloyo, Kiai Mranggi, and Kiai Monyet. The pilgrimage is attended by villagers and accompanied by various traditional arts that will perform at the Nyadran event. During the Nyadran, a replica of Kanjeng Adipati Mertoloyo, who was the founder of Jetis village, was paraded. All residents dress in traditional Javanese so that the atmosphere of the 
kingdom can be felt in Jetis Village. At that time the women were also getting ready by arranging tenong along the side of the village road.

After the pilgrimage group returns from the grave, then the women carrying tenongs participate in the pilgrimage to the village pavilion which is often known as the Sasana Krida Budaya studio which is located in the heart of the village. Arriving at the pavilion, the village history was read, prayer readings led by each of the religious leaders in turn and various traditional arts performances. The core procession of the nyadran ritual ends with the signing of the rakanan event, which is the struggle for snacks in tenong brought by the women.

After the Nyadran program, Muslims perform Friday Prayers, while Christianity, Hinduism, Buddhism and adherents of worshipers clean the nyadran area to make it tidier so that the following events can be carried out comfortably. Although the core of the Nyadran ritual has been completed, there are still various art performances such wayang kulit (shadow puppets) and traditional javanese dance staged by residents of Jetis Village and other local villagers. Because every time before Nyadran, Jetis residents also invite artists from other regions who are students of Jetis Artists.

The essence of the Nyadran program is only one day on Friday, but the excitement of the program can last up to one week starting from the Sunday before Nyadran to the Friday after Nyadran. For one week the atmosphere of Jetis Village was very busy and festive with various art performances that had been scheduled by the committee. In fact, every two years in each nyadran there is also a wayang kulit performance for one day and two nights which is staged from Saturday night to Sunday night. The joy of this Nyadran tradition is known by the local community as the village party.

For residents of Jetis Village, nyadran is not a special ritual for followers of the Islamic religion, but nyadran applies to all residents. Nyadran is a form of gratitude to God for the safety and blessings of the village, therefore all residents believe that the Nyadran tradition does not belong to a particular religion or group, but is a joint event regardless of religious differences. The interfaith leaders in Jetis Village also fully supported the success of the event. They pray for their success and mutual safety (Purwanto, 2017).

The Jetis nyadran ritual procession consists of several series of activities, namely nyadran in the grave (Giri, 2010), tenongan, traditional ceremonies at the Village Hall, rakanan, various traditional 
arts performances including horse braids, tayub, shadow puppets, kethoprak, theater, bangilun, keroncong, etc (Prayoto, 2017).

Nyadran is one of the annual activities carried out by the Javanese Muslim community. The implementation of nyadran in Javanese tradition is carried out every time before the month of Ramadan, namely in the month of Sha'ban or Ruwah. As in Grobogan Regency, the Nyadran tradition of Jetis Village has many uniqueness and is full of local wisdom, including: First, Nyadran Desa Jetis which is held in the month of Sha'ban or Ruwah as Javanese society in general, is an annual grand ritual that involves all residents. People from various cultural backgrounds, professions, and across religions. Communities with various religious backgrounds are merged into one and collectively carry out religious and cultural rituals by "abandoning" their respective religious identities.

Second, the Jetis nyadran tradition becomes an annual rite that has its own charm for its citizens. The implementation is not only carried out in one day, but is held within one week with various series of events which are full of local traditions. So that for Jetis people who already live outside the city or outside the city, the momentum of the nyadran ritual is used as an annual homecoming tradition in addition to the Eid homecoming (Idul Fitri). At this moment, all residents of the Jetis community of various ages who are outside the region and outside the city took the time to return to their hometowns together with the residents of the Nguri-uri community (preserving) a tradition that has been running for hundreds of years.

Third, Jetis nyadran, which is an annual traditional ceremony, is celebrated as a "village party" event in commemoration of the Jetis Village Anniversary. On the day of the village party, almost all residents wear traditional clothes, for women dress up in the style of the sinden, wearing kebaya and bun, while the men dress up like soldiers, wearing palace costumes, art clothes, and a variety of other costumes. During one week this celebration was held day and night with various types of local arts and culture performances involving not only local arts and culture treasures, but also presenting from various regions. In addition, this village party event is filled with various foods and snacks from the market, and along the village entrance is enlivened with a bazaar of various local potential products and various kinds of arts and culture crafts made by the local community. That is why the Jetis nyadran tradition has become one of the icons of a tourist village as well as a tourist attraction in Grobogan Regency, 
which is crowded with foreign tourists and journalists to witness and cover art-cultural performances and folk parties in this Jetis Tourism Village.

Fourth, the cost of organizing the entire series of events is very large for the size of a village, reaching 200 million rupiah, even once every two years the cost can be up to 500 million rupiah when equipped with a shadow puppet performance for one day and two nights. Most of the costs of organizing nyadran come from the Jetis Village community self-help which is carried out by way of fees. So that people already have a tradition of saving money in preparation for the annual Jetis Nyadran event (Widy, 2017).

\section{Local Wisdom in the Nyadran Jetis Tradition}

In the Nyadran tradition, there are many local wisdoms that need to be preserved. These kinds of local wisdom are able to unite the residents of Jetis Village, who consist of various religions and beliefs. When the Nyadran tradition was carried out, all the residents of Jetis Village melted together to make the event a success. So the Nyadran tradition is able to unite the pluralistic citizens. Some of the values of local wisdom that are reflected in the procession of the Jetis nyadran ritual and become important values for the harmony of the residents of Jetis Village, among others:

Togetherness in Difference

In the nyadran ritual, it appears that all citizens from various different backgrounds, both different religions and beliefs, educational backgrounds, political party affiliations, economic status, and social status are jointly involved in the success of the event. This togetherness has been well preserved for hundreds of years through the momentum of holding the Nyadran ritual.

Togetherness in Gotong Royong

The Jetis nyadran activity is a colossal event that involves many people and requires a very large fee, namely Rp. 200 million to Rp. 500 million. The implementation of nyadran also requires a lot of preparation and takes up a lot of people's time. However, for the Jetis community, Nyadran is an important annual momentum that must be successful in its implementation. This can be realized because they still uphold and maintain local wisdom, namely the spirit of mutual cooperation.

In the Jetis nyadran tradition there is local wisdom in the form of sharing with others, as reflected in the symbol of the tenongan event. 
People with various plural backgrounds, both rich and poor, all share with each other. This is done as an expression of gratitude and a sign of gratitude to God for what has been bestowed on the community in the past year. Like when Kanjeng Adipati Mertoloyo carried out his nyadran after he finished building the village. All residents gather together in a thanksgiving which is better known as the submarine village or merti desa.

\section{Respect for the Ancestors}

In the nyadran ritual, there is a procession of replicas of Adipati Mertoloyo as the founder of Jetis Village and reading of his biography. Apart from being intended as an effort to reflect and transform history to the current generation of Jetis Village, the procession is also a form of appreciation and a token of gratitude towards their predecessors who have fought for the interests of the next generation. This local wisdom is a valuable education for the generation of the nation's children who are now easy to forget the history of the struggles of their predecessors. Local wisdom in this tradition become a unifier of plural citizens prom the values described in the picture of togetherness from different religius backgrounds and beliefs that must be emphasized

\section{Tradition of Nyadran Jetis: Social Cohesion for Plural Communities}

In the Jetis nyadran tradition, it is not only full of dry local wisdom, but also local wisdom which has deep values and has become social cohesion for the local community who is very plural. The nyadran ritual no longer belongs to a particular religion, but belongs to all residents of Jetis Village. There are two very strong rooted social cohesions that have been able to become the glue for the social life of the local community, namely:

First, art-based social cohesion. Jetis Village is the storehouse of the best artists in Grobogan Regency. It is in Jetis Village that the traditional artists of Grobogan and its surroundings learn and practice art, so that this place has become the oldest candradimuka crater for the traditional artists of Grobogan Regency and its surroundings. Art for the people of Jetis Village has become part of their life. Art has become the breath of life that is able to strengthen the relationship between the plural villagers of Jetis. The tradition of Nyadran Jetis is a stage to showcase the best kinds of traditional artistic creativity for the 
community, both by the residents of Jetis Village themselves and by artists from other areas who have been educated and trained by Jetis artists. Thus, art has been able to become social cohesion for the Jetis community and its surroundings. They agreed that, even though their religions and beliefs were different, they would always be united in art (Prayoto, 2017).

The harmony of the people in Jetis Village, which is full of plurality, can last and be maintained for hundreds of years because there is an adhesive element in the form of art and culture. According to Ahmad Baehaki, art as local wisdom becomes the breath of Jetis Village, so that with the art of brotherhood and true peace it can be seen in the realm of society, everything is melted into one in the art-culture frame. In fact, they love art so much that there is a stigma that "they cannot be said to be Jetis citizens if they do not have artistic skills". That is why, in Jetis Village there is a various religions and beliefs of Art. because Jetis people have not considered art if they cannot do arts, because for them art is a symbol of social glue as well as a value that is considered important as religion (Baehaki, 2017).

Second, in the Jetis nyadran tradition there are symbols and values of local wisdom that are important to be preserved, including togetherness in diversity, togetherness in mutual cooperation, sharing with others, and respect for the services of ancestors.

Third, the local wisdom values contained in the Jetis nyadran tradition have become a very strong and rooted social cohesion for the local plural community. There are two strengths of social cohesion that can be the glue for the social life of the people of Jetis Village, namely art-based social cohesion and primordial-based social cohesion. Seeing the noble value of the Nyadran tradition in the Jetis community with a spirit full of intimacy, harmony, brotherhood and awareness of mutual giving, respect and respect for differences in religion and community beliefs, regional leaders and religious leaders try to guard against outside influences that undermine noble values.

\section{Conclusion}

First, the nyadran ritual in the Jetis Village community is carried out before the month of Ramadan, namely the month of Sha'ban or Ruwah. Nyadran for the Jetis people is not a special ritual for followers of Islam, but applies to all citizens of various religions and existing faiths. Although the core event of the nyadran ritual is only carried out 
for one day, the entire series of events is held for one week which includes activities such as Eid al-Fitr, pilgrimages to ancestral graves and village merti, traditional ceremonies, cultural carnivals, tenongan, rakanan, various bazaars. local potential products, and ended with a performance of various traditional arts involving many artists from other regions. That is why the Jetis people have made the nyadran tradition a village party and a grand annual ritual whose presence is always eagerly awaited. So the Jetis people, apart from having the Eid al-Fitr homecoming tradition like the Indonesian Muslim community in general, also have the Nyadran Syuro homecoming tradition.

Second, in the Nyadran Jetis tradition there are symbols and values of local wisdom that are important to be preserved, including togetherness in diversity, togetherness in mutual cooperation, sharing with others, and respect for the services of the ancestors.

Third, the values of local wisdom contained in the Jetis nyadran tradition have become a very strong and rooted social cohesion for the local plural community. There are two strengths of social cohesion that can be the glue for the social life of the Jetis Village community, namely art-based social cohesion and primordial-based social cohesion. The implementation of the Nyadran tradition is actually based on the efforts of village elders to maintain the value of friendship, harmony and concern for fellow citizens to share happiness. So it's not only religion-based values, but also social values such as social sensitivity between citizens who have been successful and those who are less fortunat.

\section{REFERENCES}

Baehaki. Ahmad. 2017. Interview with observers and coaches of the Grobogan arts-culture community on 21 May.

Crevello, S. 2004. Dayak land use systems and indigenous knowledge. Journal of Human Ecology. Vol. 16.

Dhavamony. Mariasusai. 1995. Fenomenologi Agama. Yogyakarta: Kanisius.

Escobar. Arturo. 1994. Welcome to Cyberia: Notes on the Anthropology of Cyberculture. Journal Current Anthropology. Vol. 35(3). 
Geertz. Clifford. 1973. Religion as a Cultural System. New York: Basic Books.

Geertz. Clifford. 1983. Abangan, Santri, Priyayi dalam Masyarakat Jawa. Jakarta: Pustaka Jaya.

Giri. Wahyana. 2010. Sajen dan Ritual Orang Jawa. Yogyakarta: Narasi.

Haba. John . 2007. Revitalisasi Kearifan Lokal: Studi Resolusi Konflik di Kalimantan Barat, Maluku, dan Poso. Jakarta: ICIP dan Eropean Commision.

Hartono. Yudi. 2012. "Kearifan Lokal Tradisi Uyen Sapi Perajut Integrasi Sosial (Studi Kasus di Desa Jonggol Kecamatan Jambon Kabupaten Ponorogo)”, dimuat dalam Jurnal Agastya, Vol. 02, No. O1.

Hogg. Jonathan. 2004. "The Ambiguity of Intellectual Engagement: Towards a Reassessment of Isaiah Berlin's Legacy,” Journal ERAS, Edisi 6.

Koentjaraningrat. 1990. Pengantar Ilmu Antropologi. Jakarta: Rineka Cipta.

Kongprasertamorn, K. 2007. Local wisdom, environmental protection and community development: the clam farmers in Tabon Bangkhusai, Phetchaburi Province, Thailand", Journal of Humanities, Vol. 10.

Madjid. Nurcholish. 2014. Pluralisme Agama di Indonesia, Ulumul Qur'an, No. 3, Vol. 95.

Marjanto. Damardjati Kun. 2012. Kearifan Lokal Lingkungan Pada Upacara Perkawinan Suku Moi di Kabupaten Sorong. Jurnal Penelitian dan Pengembangan Kebudayaan, Vol. 07, No. 02.

Prayoto. Bi. 2017. Interview with youth leaders and professional artists of Jetis Village on 21 May.

Purwanto. 2017. Interview with the religious leaders of Jetis Village on 21 May. 
Shalahuddin. Marwan. 2010. "Konservasi Budaya Lokal dalam Pembentukan Harmoni Sosial (Studi Kasus di Desa Klepu Sooko Ponorogo)", dimuat dalam JURNAL HARMONI: Jurnal Multikultural \& Multireligius, Vol. IX, No. 34.

Sukramran, Somboon. 1984. Religion, Politics and Development: The Thai Sangha's Role in Natio-nal Development and Integration", Journal of Social Science, Vol. 9 No. 12

Widy. 2017. Interview with Youth leaders of Jetis Village on 21 May. 